УДК 336.275.012.33

JEL H63

Зотиков Николай Зотикович

канд. экон. наук, ФГБОУ ВО «Чувашский государственный университет им. И. Н. Ульянова», г. Чебоксары, Российская Федерация

ORCID: 0000-0001-5631-9123

e-mail:zotikovcontrol@yandex.ru

Савдерова Алина Федоровна канд. экон. наук, ФГБОУ ВО «Чувашский государственный университет им. И. Н. Ульянова», г. Чебоксары, Российская Федерация

ORCID: 0000-0002-0521-1398

e-mail: savderova@mail.ru

\section{Nilolay Z. Zotikov}

Cand. Sci. (Econ.), Chuvash State University named after I. N. Ulyanov, Cheboksary, Russia

ORCID: 0000-0001-5631-9123

e-mail: zotikovcontrol@yandex.ru

\section{Alina F. Savderova}

Cand. Sci. (Econ.), Chuvash State University named after I. N. Ulyanov, Cheboksary, Russia

ORCID: 0000-0002-0521-1398

e-mail: savderova@mail.ru
DOI 10.26425/1816-4277-2021-7-32-42

\section{ГОСУДАРСТВЕННЫЙ ДОЛГ РОССИЙСКОЙ ФЕДЕРАЦИИ, СУБЪЕКТОВ РОССИЙСКОЙ ФЕДЕРАЦИИ И МУНИЦИПАЛЬНЫХ ОБРАЗОВАНИЙ}

Аннотация. Государственный долг - это обязательства субъектов Российской Федераиии, возникающие из государственных займов, принятых на себя Российской Федераџией, гарантии по обязательствам возвратить в той же сумме с уплатой дополнительно процентов за пользование займом. Вопрос государственного и муниципального долга и вызванная этим необходимость региональных и муниципальных заимствований особенно актуальны для субъектов Российской Федерации и муниципальных образований, так как действуюший налогово-бюджетный механизм не обеспечивает на деле принцип самостоятельности и сбалансированности бюджетов, согласно которому объем предусмотренных бюджетом расходов должен соответствовать суммарному объему доходов бюджета. По мнению авторов, недостаток средств вызван не только дефицитом бюджетов, но в большей степени - недостатками существующего налогово-бюджетного механизма. Взаимосвязь бюджетного дефицита и госдолга проявляется в последующем нарастании долговых обязательств в связи с необходимостью погашения долга и процентов за пользование им. Цель статьи - оценка долговой нагрузки на уровне государства, субъектов и муниципальных образований в нынешних экономических условиях, влияние на нее доходов соответствующих бюджетов.

Ключевые слова: государственный муниципальный долг, внутренний и внешний долг, дефицит бюджета, налоговые и неналоговые доходы, межбюджетные трансферты, золотовалютные резервы, налогово-бюджетный механизм, заимствования, обслуживание госдолга

Для цитирования: Зотиков Н.З., Савдерова А.Ф. Государственный долг Российской Федерации, субъектов Российской Федерации и муниципальных образований//Вестник университета. 2021. № 7. С. 32-42.

\section{THE STATE DEBT OF THE RUSSIAN FEDERATION, THE CONSTITUENT ENTITIES OF THE RUSSIAN FEDERATION AND MUNICIPALITIES}

\begin{abstract}
The state debt is the obligations of the constituent entities of the Russian Federation arising from the state loans assumed by the Russian Federation, guarantees for the obligations to repay in the same amount with the payment of additional interest for the use of the loan. The issue of state and municipal debt and the resulting need for regional and municipal borrowing are particularly relevant for the constituent entities of the Russian Federation and municipalities, since the current fiscal mechanism does not actually provide the principle of independence and balance of budgets, according to which the amount of budget expenditures should correspond to the total amount of budget revenues. According to the authors, the lack of funds is caused not only by the budget deficit, but to a greater extent by the shortcomings of the existing fiscal mechanism. The relationship between the budget deficit and the state debt is manifested in the subsequent increase in debt obligations due to the need to repay the debt and interest for using it. The purpose of the article is to assess the debt burden at the level of the state, constituent entities and municipalities in the current economic conditions, the impact of the revenues of the respective budgets on it.
\end{abstract}

Keywords: state municipal debt, domestic and external debt, budget deficit, tax and non-tax revenues, inter-budget transfers, gold and foreign exchange reserves, tax - budget mechanism, borrowings, public debt servicing

For citation: Zotikov N.Z., Savderova A.F. (2021) The state debt of the Russian Federation, the constituent entities of the Russian Federation and municipalities. Vestnik universiteta, no. 7, pp. 32-42. DOI: 10.26425/18164277-2021-7-32-42

(C) Зотиков Н.З., Савдерова А.Ф., 2021.

Статья доступна по лицензии Creative Commons «Attribution» («Атрибуция») 4.0. всемирная (http://creativecommons.org/licenses/by/4.0/).

(c) Zotikov N.Z., Savderova A.F., 2021.

This is an open access article under the CC BY 4.0 license (http://creativecommons.org/licenses/by/4.0/). 


\section{Введение}

«Государственный долг - это совокупность экономических отношений, возникающих между государством в лице органов власти, с одной стороны, и юридическими и физическими лицами, иностранными государствами, международными финансовыми организациями, с другой стороны, при которых государство выступает в качестве заемщика и гаранта» [9].

На практике распространено мнение, что причиной возникновения долга является дефицит бюджетов.

1. «Дефицит вынуждает отвлекать большее количество средств на обслуживание долга в ущерб расходам социально - экономического характера» [11].

2. «Дефицит местного бюджета напрямую связан с муниципальным долгом» [2].

3. «В условиях пандемии коронавируса субъекты Российской Федерации сталкиваются с угрозой образования существенного бюджетного дефицита и нарастающего государственного (муниципального) долга» [10].

Анализируя механизм формирования бюджетов различных уровней за 2003-2017 гг., авторы приходят к выводу о том, что причиной государственного долга субъектов Российской Федерации (далее - РФ) и муниципальных образований является существующий налогово-бюджетный механизм, а именно несправедливое закрепление налогов среди бюджетов, а дефицит бюджета является не первопричиной, а следствием такого закрепления налогов.

1. В условиях низкого уровня налоговых доходов «основным источником муниципальных финансов остаются межбюджетные трансферы, доля которых достигает $70 \%$ доходов местных бюджетов. Доля местных налогов составляет не более $20 \%$ налоговых доходов» [1].

2. В составе налоговых доходов консолидированного бюджета субъектов РФ велика роль федеральных налогов, незначительна доля региональных и местных налогов $(12,4 \%)$ [6].

3. «В федеральном бюджете сосредоточено 53,9\% всех налоговых доходов, 87,6\% неналоговых доходов, на 85 субъектов Федерации остается соответственно 46,1\% налоговых доходов и 12,4\% неналоговых доходов» [7].

Регионы отличаются друг от друга не только по уровню своего развития, но и по показателю «государственный долг». Так, по данным РИА Рейтинг, отношение госдолга субъекта РФ к налоговым и неналоговым доходам бюджета субъекта РФ в 2019 г. составило: по Алтайскому краю - 3,2\%; по Республике Мордовия - 211,2\%.

В этих условиях большое значение приобретает управление госдолгом, «основной задачей которого является оптимизировать затраты, которые возникают, когда финансируется дефицит бюджета» [5].

«Формы и методы долговой политики с каждым годом совершенствуются и приводят к сокращению расходов государства на обеспечение государственного займа» [8].

По мнению С. В. Бжихотлова, «большие размеры внутреннего и внешнего долга, а также рост расходов на его обслуживание актуализируют как саму проблему долга, так и направления совершенствования управления долгом» [4].

\section{Исследование}

Рассмотрим внутренний и внешний долг РФ за 2010-2020 гг. (табл. 1).

Таблица 1

Внутренний долг Российской Федерации за 2010-2020 гг.

\begin{tabular}{|c|c|c|c|c|c|c|c|c|c|c|}
\hline \multirow[b]{2}{*}{ Год } & \multicolumn{2}{|c|}{ ВВП } & \multicolumn{3}{|c|}{$\begin{array}{c}\text { Доходы федерального } \\
\text { бюджета }\end{array}$} & \multicolumn{2}{|c|}{$\begin{array}{c}\text { Налоговые и не- } \\
\text { налоговые доходы }\end{array}$} & \multicolumn{3}{|c|}{ Внутренний долг } \\
\hline & $\begin{array}{c}\text { млрд } \\
\text { руб. }\end{array}$ & $\begin{array}{c}\text { темп } \\
\text { ро- } \\
\text { ста,\% }\end{array}$ & $\begin{array}{c}\text { млрд } \\
\text { руб. }\end{array}$ & $\begin{array}{c}\text { в } \% \\
\text { от ВВП }\end{array}$ & $\begin{array}{c}\text { дефицит, } \\
\text { профи- } \\
\text { цит, млрд. } \\
\text { руб. }\end{array}$ & $\begin{array}{c}\text { млрд } \\
\text { руб. }\end{array}$ & $\begin{array}{c}\text { В } \% \\
\text { от ВBП }\end{array}$ & $\begin{array}{c}\text { млрд } \\
\text { руб. }\end{array}$ & $\begin{array}{c}\text { В } \% \\
\text { от ВВП }\end{array}$ & $\begin{array}{c}\text { в \% к на- } \\
\text { логовым } \\
\text { и ненало- } \\
\text { говым } \\
\text { доходам }\end{array}$ \\
\hline 2010 & 46308,5 & - & 8304,9 & 17,9 & $-1812,0$ & 8304,6 & 17,9 & 2940,39 & 6,3 & 35,4 \\
\hline 2011 & 60114,0 & 129,8 & 11367,5 & 18,9 & 442,0 & 11338,6 & 18,9 & 4190,55 & 7,0 & 36,9 \\
\hline 2012 & 68103,4 & 113,3 & 12855,5 & 18,9 & $-39,4$ & 12790,9 & 18,8 & 4977,9 & 7,3 & 38,9 \\
\hline
\end{tabular}


Окончание табл. 1

\begin{tabular}{|c|c|c|c|c|c|c|c|c|c|c|}
\hline \multirow[b]{2}{*}{ Год } & \multicolumn{2}{|c|}{ ВВП } & \multicolumn{3}{|c|}{$\begin{array}{c}\text { Доходы федерального } \\
\text { бюджета } \\
\end{array}$} & \multicolumn{2}{|c|}{$\begin{array}{c}\text { Налоговые и не- } \\
\text { налоговые доходы }\end{array}$} & \multicolumn{3}{|c|}{ Внутренний долг } \\
\hline & $\begin{array}{c}\text { млрд } \\
\text { руб. }\end{array}$ & $\begin{array}{c}\text { темп } \\
\text { ро- } \\
\text { ста,\% }\end{array}$ & $\begin{array}{c}\text { млрд } \\
\text { руб. }\end{array}$ & $\begin{array}{c}\text { в \% } \\
\text { от ВВП }\end{array}$ & $\begin{array}{c}\text { дефицит, } \\
\text { профи- } \\
\text { цит, млрд. } \\
\text { руб. }\end{array}$ & $\begin{array}{c}\text { млрд } \\
\text { руб. }\end{array}$ & $\begin{array}{c}\text { в \% } \\
\text { от ВВП }\end{array}$ & $\begin{array}{l}\text { млрд } \\
\text { руб. }\end{array}$ & $\begin{array}{c}\text { в \% } \\
\text { от ВВП }\end{array}$ & $\begin{array}{c}\text { в \% к на- } \\
\text { логовым } \\
\text { и ненало- } \\
\text { говым } \\
\text { доходам }\end{array}$ \\
\hline 2013 & 72985,7 & 107,2 & 13019,9 & 17,8 & $-323,0$ & 12968,8 & 17,8 & 5722,24 & 7,8 & 44,1 \\
\hline 2014 & 79030,0 & 108,3 & 14496,9 & 18,3 & $-334,7$ & 14385,9 & 18,2 & 7241,17 & 9,2 & 50,3 \\
\hline 2015 & 83087,4 & 105,1 & 13659,2 & 16,4 & $-1961,0$ & 13399,0 & 16,1 & 7307,61 & 8,8 & 54,5 \\
\hline 2016 & 85616,1 & 103,0 & 13460,0 & 15,7 & $-2956,4$ & 13307,9 & 15,5 & 8003,46 & 9,3 & 60,1 \\
\hline 2017 & 91843,2 & 107,3 & 15088,9 & 16,4 & $-1331,4$ & 15047,4 & 16,4 & 8689,63 & 9,5 & 57,7 \\
\hline 2018 & 103861,7 & 113,1 & 19454,4 & 18,7 & 2741,3 & 19401,0 & 18,7 & 9169,63 & 8,8 & 47,3 \\
\hline 2019 & 109193,2 & 105,1 & 20188,8 & 18,3 & 1974,3 & 20114,1 & 18,4 & 10171,93 & 9,3 & 50,6 \\
\hline 2020 & 106606,6 & 97,6 & 18722,2 & 17,6 & $-4099,3$ & 17594,2 & 16,5 & 14790,47 & 13,9 & 84,1 \\
\hline Итого & 906749,8 & - & 160818,2 & 17,7 & $-7699,6$ & 158652,4 & 17,5 & 83204,93 & 9,2 & 52,4 \\
\hline $\begin{array}{c}2020 \text { г. } \\
\text { к } 2010 \text { г., } \\
\%\end{array}$ & 230,2 & - & 225,4 & 98,3 & - & 211,9 & 92,2 & 5 раз & 220,6 & 237,6 \\
\hline
\end{tabular}

Источники: [12; 13; 14; 15; 16]

Согласно данным таблицы 1, в 2020 г. по сравнению с 2010 г.:

- ВВП увеличился в 2,3 раза;

- доходы федерального бюджета увеличились в 2,25 раза, что привело к снижению доли на 1,7\% в процентах от ВВП;

- в 2020 г. дефицит составил $21,9 \%$ от доходов бюджета, что вызвано снижением ВВП на 2,4\%;

- налоговые и неналоговые доходы увеличились в 2,1 раза, в то же время снизились на 7,8\% в процентах от ВВП;

- внутренний долг увеличился в 5 раз, в процентах от ВВП - в 2,2 раза (в 2010 г. - 6,3\% от ВВП, в 2020 г. $-13,9 \%$ от ВВП);

- увеличение собственных доходов в меньшем размере (в 2,1 раза), чем доходы федерального бюджета (в 2,25 раза), привело к увеличению внутреннего долга в процентах от собственных доходов бюджета в большем размере (в 2,37 раза) (в 2010 г. - 35,4\%, в 2020 г. - 84,1\%).

Максимальное значение внутреннего долга к объему ВВП Россия имеет в 2020 г. (13,9\%). Совокупный государственный долг (внутренний и внешний) в 2020 г. составил 19\% от ВВП (в бюджете на 2021 г. - 20,3\% от ВВП).

Для сравнения: в 2020 г. государственный долг США составил 27,553 трлн долл. США при ВВП 20,81 трлн долл. США (в 2010 г. - 13,528 трлн долл. США). При этом ВВП США на душу населения по итогам 2019 г. составил 65,25 тыс. долл. США [17]. В России ВВП на душу населения - 11,6 тыс. долл. США. Государственный долг Китая в 2019 г. составил 52,6\% от ВВП, ВВП на душу населения - 10,52 тыс. долл. США [18].

Рассмотрим объемы государственного внешнего долга РФ за 2010-2020 гг. (табл. 2).

Согласно данным таблицы 2, внешний долг России в 2020 г. по сравнению с 2010 г. уменьшился на 3,8\%, его доля в ВВП уменьшилась с $32 \%$ в 2010 г. до $30 \%$ в 2020 г. или на $6,3 \%$.

Наиболее резкий рост средств ФНБ произошел в 2020 г. (рост против 2019 г. на 74,2\%), увеличился и внутренний долг (на 45,4\%). Величина Фонда национального благосостояния увеличилась в 5 раз, по отношению к ВВП - в 2,2 раза.

Золотовалютные резервы России достигли исторического максимума в августе 2020 г. - 600,7 млрд долл. США, превысив показатель достаточности. 
Объем государственного внешнего долга РФ

\begin{tabular}{|c|c|c|c|c|c|c|c|}
\hline \multirow[b]{2}{*}{ Год } & \multicolumn{2}{|c|}{ Внешний долг } & \multirow[b]{2}{*}{$\begin{array}{c}\text { Фонд националь- } \\
\text { ного благосостоя- } \\
\text { ния, млрд руб. }\end{array}$} & \multirow[b]{2}{*}{$\begin{array}{c}\text { Внутренний } \\
\text { долг, млрд } \\
\text { руб. }\end{array}$} & \multicolumn{2}{|c|}{ Золотовалютные резервы } & \multirow{2}{*}{$\begin{array}{c}\text { Цена } \\
\text { на нефть, } \\
\text { долл. США/ } \\
\text { барр. }\end{array}$} \\
\hline & $\begin{array}{l}\text { млрд } \\
\text { долл. } \\
\text { США } \\
\end{array}$ & $\begin{array}{c}\text { в \% } \\
\text { от ВВП }\end{array}$ & & & $\begin{array}{c}\text { млрд долл. } \\
\text { США }\end{array}$ & $\begin{array}{c}\text { достаточная } \\
\text { сумма }\end{array}$ & \\
\hline 2010 & 488,5 & 32 & 2695,52 & 2940,39 & 479,4 & 238,4 & 79,6 \\
\hline 2011 & 538,8 & 26 & 2794,43 & 4190,55 & 498,6 & 279,5 & 111,0 \\
\hline 2012 & 636,4 & 29 & 2690,63 & 4977,9 & 537,6 & 315,7 & 111,4 \\
\hline 2013 & 728,8 & 32 & 2900,64 & 5722,24 & 509,6 & 352,0 & 108,8 \\
\hline 2014 & 599,9 & 29 & 4388,09 & 7241,17 & 385,4 & 282,8 & 98,9 \\
\hline 2015 & 518,4 & 38 & 5227,18 & 7307,61 & 368,4 & 198,2 & 52.4 \\
\hline 2016 & 511,7 & 40 & 4359,16 & 8003,46 & 377,7 & 200,3 & 44,0 \\
\hline 2017 & 518,4 & 33 & 3752,94 & 8689,63 & 432,7 & 218,3 & 54,53 \\
\hline 2018 & 455,1 & 27 & 4036,07 & 9169,63 & 468,5 & 195,3 & 72,93 \\
\hline 2019 & 491,4 & 29 & 7773,62 & 10171,93 & 554,3 & 208,9 & 63,33 \\
\hline 2020 & 470,1 & 30 & 13541,7 & 14790,47 & 595,8 & н/д & 51,8 \\
\hline $\begin{array}{c}2020 \\
\text { к } 2010, \\
\%\end{array}$ & 96,2 & 93,7 & 5 раз & 5 раз & 124,3 & - & 65,1 \\
\hline
\end{tabular}

Источники: [19; 20;21;22]

В 2020 г. падение цен на нефть составило 34,9\% против цен 2010 г. Максимальная цена на нефть была в 2012 г. (111,4 долл. США за баррель), минимальная - в 2016 г. (44,0 долл. США за баррель). Цены на нефть марки Brent резко снизились в 2008 г. (на 54,5\%), в 2014 г. (на 43,8\%), на нефть марки Urals - в 2015 г. (на 47,5\%), то есть в кризисные периоды. После заключения Соглашения с ОПЕК+ цены на нефть повысились.

Таблица 3

Долг субъектов РФ и муниципальных образований

\begin{tabular}{|c|c|c|c|c|c|c|c|c|}
\hline \multirow[b]{2}{*}{ Год } & \multicolumn{3}{|c|}{$\begin{array}{l}\text { Доходы консолидированных бюд- } \\
\text { жетов субъектов РФ, млрд руб. }\end{array}$} & \multicolumn{3}{|c|}{$\begin{array}{c}\text { Объем госдолга субъектов РФ } \\
\text { и муниципальных образований, } \\
\text { млрд руб. }\end{array}$} & \multicolumn{2}{|c|}{$\begin{array}{c}\text { Объем госдолга, } \\
\text { в \% к }\end{array}$} \\
\hline & всего & $\begin{array}{c}\text { в том чи- } \\
\text { сле на- } \\
\text { логовые } \\
\text { и ненало- } \\
\text { говые до- } \\
\text { ходы }\end{array}$ & $\begin{array}{l}\text { дефицит/ } \\
\text { профицит }\end{array}$ & всего & $\begin{array}{c}\text { субъектов } \\
\text { РФ }\end{array}$ & $\begin{array}{c}\text { муниципа- } \\
\text { литетов }\end{array}$ & $\begin{array}{c}\text { доходам } \\
\text { бюджетов }\end{array}$ & $\begin{array}{c}\text { налоговым } \\
\text { и неналого- } \\
\text { вым доходам }\end{array}$ \\
\hline 2010 & 6537,3 & 5025,6 & $-99,5$ & 1265,8 & 1096,0 & 169,8 & 19,4 & 25,2 \\
\hline 2011 & 7644,2 & 5875,4 & $-34,9$ & 1387,3 & 1171,8 & 215,5 & 18,1 & 23,6 \\
\hline 2012 & 8064,5 & 6384,4 & 278,6 & 1596,7 & 1351,4 & 245,3 & 19,8 & 25,0 \\
\hline
\end{tabular}


Окончание табл. 3

\begin{tabular}{|c|c|c|c|c|c|c|c|c|}
\hline \multirow[b]{2}{*}{ Год } & \multicolumn{3}{|c|}{$\begin{array}{c}\text { Доходы консолидированных бюд- } \\
\text { жетов субъектов РФ, млрд руб. }\end{array}$} & \multicolumn{3}{|c|}{$\begin{array}{c}\text { Объем госдолга субъектов РФ } \\
\text { и муниципальных образований, } \\
\text { млрд руб. }\end{array}$} & \multicolumn{2}{|c|}{$\begin{array}{c}\text { Объем госдолга, } \\
\text { в \% к }\end{array}$} \\
\hline & всего & $\begin{array}{c}\text { в том чи- } \\
\text { сле на- } \\
\text { логовые } \\
\text { и ненало- } \\
\text { говые до- } \\
\text { ходы }\end{array}$ & $\begin{array}{l}\text { дефицит/ } \\
\text { профицит }\end{array}$ & всего & $\begin{array}{c}\text { субъектов } \\
\text { РФ }\end{array}$ & $\begin{array}{l}\text { муниципа- } \\
\text { литетов }\end{array}$ & $\begin{array}{c}\text { доходам } \\
\text { бюджетов }\end{array}$ & $\begin{array}{c}\text { налоговым } \\
\text { и неналого- } \\
\text { вым доходам }\end{array}$ \\
\hline 2013 & 8165,1 & 6588,5 & $-641,4$ & 2026,4 & 1737,5 & 288,9 & 24,8 & 30,7 \\
\hline 2014 & 8905,6 & 7177,3 & $-447,6$ & 2402,7 & 2089,5 & 313,2 & 27,0 & 33,5 \\
\hline 2015 & 9308,1 & 7625,1 & $-171,6$ & 2660,7 & 2318,6 & 342,1 & 28,6 & 34,9 \\
\hline 2016 & 9923,8 & 8289,3 & $-12,6$ & 2717,5 & 2353,2 & 364,3 & 27,4 & 32,8 \\
\hline 2017 & 10758,1 & 8986,5 & $-51,9$ & 2683,4 & 2315,4 & 368,0 & 24,9 & 29,9 \\
\hline 2018 & 12392,4 & 10222,2 & 510,3 & 2578,2 & 2206,3 & 371,9 & 20,8 & 25,2 \\
\hline 2019 & 13568,0 & 10990,9 & 4,7 & 2493,2 & 2113,0 & 380,2 & 18,4 & 22,7 \\
\hline 2020 & 14897,5 & 10796,5 & $-676,6$ & 2884,3 & 2496,6 & 387,7 & 19,4 & 26,7 \\
\hline $\begin{array}{l}\text { Итого } \\
2020\end{array}$ & 110164,6 & 87961,7 & $-1342,5$ & 24696,2 & 21249,3 & 3446,9 & 22,4 & 28,1 \\
\hline $\begin{array}{c}\text { к } 2010, \\
\%\end{array}$ & 227,9 & 214,8 & - & 227,9 & 227,8 & 228,3 & 100,0 & 105,9 \\
\hline
\end{tabular}

Источники: [13; 14; 15;24]

Из данных таблицы 3 следует, что в 2020 г. по сравнению с 2010 г.:

- доходы консолидированных бюджетов субъектов РФ увеличились в 2,27 раза, в том числе налоговые и неналоговые доходы - в 2,15 раза;

- доходы бюджетов субъектов РФ и объемы госдолга субъектов РФ и муниципальных образований увеличились в одинаковом размере (в 2,28 раза);

- объем госдолга субъектов РФ стал увеличиваться, начиная с 2013 г. В 2017-2019 гг. наблюдается снижение долга. В 2020 г. величина долга резко увеличилась (в связи с пандемией COVID-19);

- доходы консолидированных бюджетов субъектов РФ имели профицит в 2012 г. (3,4\% от доходов бюджета), в 2018 г. - 4,1\% и в 2019 г. -0,03\%. В 2010 г. дефицит бюджета составил 99,5 млрд руб. (1,5\% от доходов), в 2020 г. - 676,6 млрд руб. (4,5\%);

- объем государственного долга субъектов РФ и муниципалитетов увеличился в 2,27 раза (19,4\% доходов бюджета в 2010 г. и 2020 г.); в 2014-2015 г. показатель имел максимальное значение (27,0-28,6\%), в процентах от налоговых и неналоговых доходов бюджетов увеличился с 25,2\% в 2010 г. до 26,7\% в 2020 г. или на 5,9\%. Максимальное значение показатель имел в 2014-2015 гг. (33,5-34,9\%);

- вывод А. А. Белостоцкого [3] об имеющейся тенденции снижения удельного веса налоговых и неналоговых доходов до 81,0\% в 2019 г. подтверждается данными за 2020 г. (72,5\%);

- снижение собственных доходов бюджетов, увеличение государственного долга субъектов РФ в абсолютном выражении на 383,6 млрд руб. (или на 18,1\%) привели к увеличению в 2020 г. по сравнению с 2019 г. объема госдолга в процентах от доходов бюджета от 18,4\% до 19,4\%, в процентах к собственным доходам бюджетов - с $22,7 \%$ до 26,7\%. Отношение суммарного государственного долга к объему налоговых и неналоговых доходов бюджетов на начало 2020 г. составило 22,55 (от $0 \%$ в г. Севастополь и Сахалинской области до 211,2\% в республике Мордовия). 
На 1 января 2020 г. 37 регионов имели госдолг, превышающий половину собственных доходов бюджетов, из них 14 регионов - превышающий $70 \%$ собственных доходов бюджетов.

Из сравнения данных таблиц 1 и 3 видно, что в 2020 г. по сравнению с 2010 г. внутренний долг РФ в абсолютном выражении увеличился в 5 раз, в процентах к собственным доходам бюджета - в 2,37 раза, долг субъектов РФ и муниципальных образований - в 2,27 раза, в процентах от собственных доходов - на 5,9\%. В 2011 г. у 68 субъектов РФ суммарный объем государственного долга субъекта РФ был меньше $50 \%$ объема собственных доходов консолидированного бюджета, у трех регионов - от 50 до 60\%, четырех регионов - от 60 до 70\%, пяти регионов - свыше 70\%. В 2019 г. у шести регионов госдолг превышал $70 \%$ объема собственных доходов бюджета, у одиннадцати регионов - от $60-70 \%$, у десяти регионов - от $50 \%$ до $60 \%$, и лишь 55 регионов имели долг на уровне менее $50 \%$ собственных доходов бюджета.

Для обобщения выводов составим сводную таблицу долга за 2010-2020 гг. (табл. 4).

Таблица 4

Внутренний государственный долг РФ и долг субъектов РФ и муниципальных образований за 2010-2020 гг.

\begin{tabular}{|l|c|c|c|}
\hline \multicolumn{1}{|c|}{ Показатель } & РФ & Субъекты РФ & Всего \\
\hline ВВП, млрд руб. & 906749,8 & - & 906749,8 \\
Доходы бюджетов, млрд руб. & 160618,2 & 110164,6 & 270782,8 \\
Доходы бюджетов, \% & 59,3 & 40,7 & 100,0 \\
Налоговые и неналоговые доходы, млрд руб. & 158652,4 & 87961,7 & 246614,1 \\
Налоговые и неналоговые доходы, \% & 64,3 & 35,7 & 100,0 \\
Межбюджетные трансферты, млрд руб. & 1965,8 & 22202,9 & 24168,7 \\
в \% от доходов & 1,2 & 20,1 & 100,0 \\
в \% от общей суммы трансфертов & 8,1 & 91,9 & 100,0 \\
Внутренний долг, млрд руб. & 83204,93 & 24696,2 & 107901,13 \\
в \% от ВВП & 9,2 & - & 11,9 \\
в \% от налоговых и неналоговых доходов & 52,4 & 28,1 & 43,7 \\
Дефицит бюджетов, млрд руб. & 7699,6 & 1342,5 & 9042,1 \\
Отношение госдолга к дефициту, раз & 10,8 & 18,4 & 11,9 \\
\hline
\end{tabular}

Составлено авторами по материалам исследования

В целом за период с 2010 г. по 2020 г.:

- доходы федерального бюджета составляют 17,7\% от ВВП;

- налоговые и неналоговые доходы $-17,5 \%$ от ВВП;

- внутренний долг - 9,2\% от ВВП и 52,4\% от налоговых и неналоговых доходов бюджета;

- внутренний долг РФ в 10,8 раз превышает величину дефицита. Дефицит консолидированных бюджетов субъектов РФ составил 1342,5 млрд руб.;

- долг муниципальных образований (3446,9 млрд руб.) составил 13,9\% от общего объема госдолга субъектов РФ и муниципальных образований;

- объем госдолга составляет $22,4 \%$ доходов консолидированных бюджетов субъектов РФ и $28,1 \%$ от суммы налоговых и неналоговых доходов бюджетов.

В доходах федерального бюджета сосредоточено 59,3 \% общей суммы доходов, 64,3 \% собственных доходов, $1,2 \%$ всей суммы межбюджетных трансфертов, в доходах консолидированного бюджета субъектов РФ - соответственно 40,7\%, 35,7\%, 98,8\%. 
Рассмотрим структуру государственного долга субъектов и муниципальных образований (табл. 5).

Структура госдолга субъектов РФ и муниципальных образований

\begin{tabular}{|l|c|c|c|c|c|c|c|c|c|}
\hline \multicolumn{1}{|c|}{ Показатель } & $\mathbf{2 0 1 0}$ г. & $\mathbf{2 0 1 1}$ г. & $\mathbf{2 0 1 5}$ г. & $\mathbf{2 0 1 6}$ г. & $\mathbf{2 0 1 7}$ г. & $\mathbf{2 0 1 8}$ г. & $\mathbf{2 0 1 9}$ г. & $\mathbf{2 0 2 0}$ г. & $\begin{array}{c}\mathbf{2 0 2 0} \text { г. } \\
\text { к 2010 г., \% }\end{array}$ \\
\hline \multicolumn{8}{|c|}{ Государственный долг субъектов РФ } \\
\hline $\begin{array}{l}\text { Госдолг - всего, млрд.руб. } \\
\text { Государственные ценные бу- } \\
\text { маги, млрд.руб. }\end{array}$ & 1096,0 & 1171,8 & 2318,6 & 2353,2 & 2315,4 & 2206,3 & 2113,0 & 2496,0 & 227,7 \\
Кредиты банков, млрд.руб. & 200,4 & 283,9 & 432,8 & 457,5 & 548,5 & 551,4 & 588,5 & 769,9 & 189,1 \\
Бюджетные кредиты, млрд.руб. & 340,1 & 419,4 & 808,7 & 990,5 & 1010,3 & 940,0 & 876,8 & 1094,1 & 321,7 \\
\hline \multicolumn{8}{|c|}{ Долг муниципальных образований } \\
\hline Долг - всего, млрд.руб. & 169,8 & 215,5 & 342,1 & 364,3 & 368 & 371,9 & 380,2 & 387,7 & 228,3 \\
Муниципальные ценные бу- & 8,3 & 7,2 & 10,2 & 15,5 & 21,1 & 18,1 & 21,3 & 24,6 & 296,4 \\
маги, млрд.руб. & 71,9 & 97,2 & 205,5 & 226,8 & 241,2 & 256,5 & 259,5 & 264,7 & 368,1 \\
Кредиты банков, млрд.руб. \\
Бюджетные кредиты, млрд.руб.
\end{tabular}

Источник: [23]

Согласно данным таблицы 5, в 2020 г. по сравнению с 2010 г.:

- доля государственного долга субъектов РФ в общей сумме государственного долга осталась без изменения $(86,5 \%)$;

- доля государственных ценных бумаг уменьшилась с 37,1 \% до 30,8\% или на $17,0 \%$, при этом резкое падение доли ценных бумаг имело место в 2015 г. (18,7\%), 2016 г. (19,4\%);

- доля кредитов кредитных организаций с 18,3\% увеличилась до $22,8 \%$ или на $24,6 \%$, в 2015 г. доля кредитов банков увеличивалась до 40,2\%;

- доля бюджетных кредитов из года в год увеличивается, их доля в 2020 г. достигла 43,8 \%, увеличившись с 31,0\% в 2010 г. на 41,3\% (ставка по бюджетным кредитам намного меньше ставок по кредитам, предоставляемым кредитными учреждениями);

- доля государственных гарантий уменьшилась с 10,6\% до 1,5\%;

- в составе долга муниципальных образований доля кредитов банков увеличилась с 42,3\% до 68,3\% или на $61,5 \%$;

- доля бюджетных кредитов уменьшилась с 37,3\% до 23,5\% или на 37,0\%;

- незначительна доля муниципальных ценных бумаг (6,3\% в 2020 г.), муниципальных гарантий $(1,6 \%$ в 2020 г.).

Рассмотрим основные показатели исполнения местных бюджетов в РФ (табл. 6).

Таблица 6

Основные показатели исполнения местных бюджетов в РФ

\begin{tabular}{|l|c|c|c|}
\hline \multicolumn{1}{|c|}{ Показатель } & $\mathbf{2 0 1 9}$ г. & $\mathbf{2 0 2 0}$ г. & $\mathbf{2 0 2 0}$ г. к 2019 г., \% \\
\hline Доходы - всего, млрд руб. & 4722,8 & 5049,9 & 106,9 \\
Собственные доходы, млрд руб. & 3176,7 & 3402,0 & 107,1 \\
Налоговые и неналоговые доходы, млрд руб. & 1607,7 & 1647,3 & 102,5 \\
в том числе налоговые доходы, млрд руб. & 1340,7 & 1404,5 & 104,8 \\
\hline
\end{tabular}


Окончание табл. 6

\begin{tabular}{|l|c|c|c|}
\hline \multicolumn{1}{|c|}{ Показатель } & $\mathbf{2 0 1 9}$ г. & $\mathbf{2 0 2 0}$ г. & $\mathbf{2 0 2 0}$ г. к 2019 г., \% \\
\hline то же, в \% к собственным доходам & 42,2 & 41,3 & - \\
Межбюджетные трансферты, млрд руб. & 1569,0 & 1754,7 & 111,8 \\
то же, в \% к собственным доходам & 49,4 & 51,6 & - \\
в том числе: & & & 124,5 \\
дотации, млрд руб. & 437,6 & 544,7 & - \\
то же, в \% от межбюджетных трансфертов & 27,9 & 31,0 & 106,6 \\
субсидии, млрд руб. & 852,9 & 909,1 & - \\
то же, в \% от межбюджетных трансфертов & 54,4 & 51,8 & 101,9 \\
Объем муниципального долга, млрд руб. & 380,3 & 387,4 & - \\
то же, в \% от налоговых и неналоговых доходов & 23,6 & 23,5 & \\
\hline
\end{tabular}

Источник: [24]

Как следует из данных таблицы 5, в 2020 г. по сравнению с 2019 г. доходы местных бюджетов увеличились на $6,9 \%$, в том числе собственные доходы - на 7,1\%, из них межбюджетные трансферты на $11,8 \%$ (их доля в процентах к собственным доходам увеличилась с 49,4\% до 51,6\%. Таким образом, доходы местных бюджетов формируются на $1 / 2$ за счет межбюджетных трансфертов (доля дотаций составила в 2020 г. $31,0 \%$, доля субсидий $-51,8 \%$ ). Объем долга муниципальных образований увеличился на $1,9 \%$ и составил в 2020 г. 23,5\% от величины налоговых и неналоговых доходов местных бюджетов.

\section{Заключение}

При увеличении в 2020 г. по сравнению с 2010 г. объема ВВП в 2,3 раза внутренний долг РФ увеличился в 5 раз, его доля в ВВП с 6,3\% до $13,9 \%$, с 35,4\% собственных доходов бюджета до 84,1 \%, что обусловлено снижением налоговых и неналоговых доходов в ВВП с 17,9\% до 16,5\%.

При уменьшении внешнего долга РФ в 2020 г. по сравнению с 2010 г. на 3,8\% его доля в ВВП снизилась с $32 \%$ до $30 \%$.

В 2020 г. по сравнению с 2010 г. средства Фонда национального благосостояния увеличились в 5 раз (при снижении цены на нефть на $34,9 \%$ ).

Объем государственного долга субъектов РФ и муниципальных образований увеличился по сравнению с 2010 г. в 2,27 раза, в том числе объем государственного долга в процентах от налоговых и неналоговых доходов - с 25,2\% до 28,1\%. Доля собственных доходов в консолидированном бюджете субъектов РФ имеет тенденцию к снижению.

Государственный долг субъектов РФ на 1 января 2020 г. превышает 50 \% объема налоговых и неналоговых доходов в 37 субъектах РФ, из них в 14 субъектах - более $70 \%$.

Внутренний долг РФ в целом за 2010-2020 гг. превышает величину дефицита федерального бюджета за этот период в 10,8 раза, долг субъектов РФ дефицит соответствующих бюджетов в 18,4 раза.

Наличие госдолга не связано с дефицитом бюджетов. Так, государственный долг РФ в 2019 г. составил 10 171,93 млрд руб. при профиците бюджета за этот период в сумме 1 974,3 млрд руб. Внутренний долг субъектов РФ в 2019 г. составил 2 493,2 млрд руб. при профиците бюджета в сумме 4,7 млрд руб.

Наличие государственного долга субъектов РФ и муниципалитетов связано с закреплением за ними малоэффективных налогов, а также передачей на низший уровень управления функций без их подкрепления финансами. Местные бюджеты наполовину формируются за счет межбюджетных трансфертов. В величине налоговых доходов местных бюджетов за 2020 г. (1404,5 млрд руб.) доля федерального налога НДФЛ составила 907,2 млрд руб. или 64,8\% (доля местных налогов не превышает 1/3 доходов бюджетов).

Исследование свидетельствует о наличии прямой зависимости долга субъектов РФ и муниципалитетов от налоговых и неналоговых доходов. 
В целях сокращения долга субъектов РФ и долга муниципальных образований необходимым является перезакрепление налоговых доходов в их пользу.

\section{Библиографический список}

1. Арланова, О. И., Зотиков, Н. З., Львова, М. В. Местные бюджеты: проблемы формирования // Вестник Евразийской науки. - 2019. - Т. 11, № 5 [Электронный ресурс]. - Режим доступа: https:/esj.today/PDF/15ECVN519.pdf (дата обращения: 08.05.2021).

2. Баронецкая, Н. Э. Оценка управления дефицитом местного бюджета и муниципальным долгом // Мировая экономика: проблемы безопасности. - 2020. - № 4. - С. 21-27.

3. Белостоцкий, А. А. Практика исполнения консолидированных бюджетов и снижение уровня государственного долга субъектов РФ // Актуальные проблемы развития хозяйствующих субъектов, территорий и систем регионального и муниципального управления: материалы XV международной научно-практической конференции. Курск, 24-25 мая, 2020 г. - Курск: Юго-Западный государственный университет, 2020. - С. 51-54.

4. Бжихатлов, С. Х., Нагаев, А. А. Особенности управления государственным долгом // Актуальные вопросы экономических наук. - 2016. - № 50-2. - С. 11-16.

5. Джинджолия, А. О. Развитие методов и инструментов управления государственным (муниципальным) долгом // Вестник науки и образования. - 2019. - № 9-1 (63). - С. 54-58.

6. Зотиков, Н. З., Львова, М. В., Арланова, О. И. Особенности и проблемы формирования бюджетов субъектов РФ // Инновационное развитие экономики. - 2019. - № 2 (50). - С. 205-218.

7. Зотиков, Н. З., Львова, М. В., Арланова, О. И. Особенности формирования доходов федерального бюджета // Вестник Евразийской науки. - 2019. - Т. 11, № 1 [Электронный ресурс]. - Режим доступа: https:/esj.today/PDF/12ECVN119.pdf (дата обращения: 08.05.2021).

8. Рощин, Н. С. Особенности организации государственных и муниципальных заимствований в зарубежных государствах // Бизнес-образование в экономике знаний. - 2020. - № 2 (16). - С. 76-82.

9. Мохнаткина, Л. Б. Государственный и муниципальный долг: учебное пособие. - Оренбург: ОГУ, 2013 - 180 с.

10. Ткаченко, Р. В. Бюджетное регулирование в условиях предотвращения последствий распространения новой коронавирусной инфекции на территории Российской Федерации // Lex russica (Русский закон). - 2021. - № 2 (171). - С. 64-79. https://doi.org/10.17803/1729-5920.2021.171.2.064-079

11. Норкин, А. В., Смирнова, И. А., Коробова, В. Ф. Государственные заимствования субъекта Российской Федерации в контексте нового понятия «долговой устойчивости» региона // Вестник Алтайской академии экономики и права. 2019. - № 7-2. - C. 61-67. https://doi.org/10.17513/vaael.651

12. ВВП России по годам: 1991-2020 // Мировые финансы [Электронный ресурс]. - Режим доступа: http://global-finances. ru/vvp-rossii-po-godam/ (дата обращения: 08.05.2021).

13. Отчеты об исполнении консолидированного бюджета Российской Федерации и государственных внебюджетных фондов за 2010-2018 годы // Минфин РФ [Электронный ресурс]. - Режим доступа: https://minfin.gov.ru/ru/statistics/conbud/ (дата обращения: 08.05.2021).

14. Исполнение федерального бюджета и бюджетов бюджетной системы Российской Федерации за 2019 год. - М.: Министерство финансов Российской Федерации, 2020 [Электронный ресурс]. - Режим доступа: https://minfin.gov.ru/common/ upload/library/2020/09/main/Ispolnenie_federalnogo_budzheta_2019_god.pdf (дата обращения: 08.05.2021).

15. Исполнение федерального бюджета и бюджетов бюджетной системы Российской Федерации за 2020 год (предварительные итоги). - М.: Министерство финансов Российской Федерации, 2020 [Электронный ресурс]. - Режим доступа: https://minfin.gov.ru/common/upload/library/2021/03/main/Ispolnenie_2020_god.pdf (дата обращения: 08.05.2021).

16. Внутренний государственный долг России: 1993-2021 // Мировые финансы [Электронный ресурс]. - Режим доступа: http://global-finances.ru/vnutrenniy-dolg-rossii/ (дата обращения: 08.05.2021).

17. Госдолг США в 2021 г. превысил 28 триллионов долларов // Мировые финансы [Электронный ресурс]. - Режим доступа: http://global-finances.ru/gosdolg-ssha/ (дата обращения: 08.05.2021).

18. ВВП США по годам: 1980-2021 // Мировые финансы [Электронный ресурс]. - Режим доступа: http://global-finances.ru/ vvp-ssha-po-godam/ (дата обращения: 08.05.2021).

19. Внешний долг России: 1994-2021 // Мировые финансы [Электронный ресурс]. - Режим доступа: http://global-finances. ru/vneshniy-dolg-rossii/ (дата обращения: 08.05.2021). 
20. Золотовалютные резервы России: 1994-2021 // Мировые финансы [Электронный ресурс]. - Режим доступа : http://globalfinances.ru/zolotovalyutnyie-rezervyi-rossii/ (дата обращения: 08.05.2021).

21. Фонд национального благосостояния России: 2008-2021 // Мировые финансы [Электронный ресурс]. - Режим доступа: http://global-finances.ru/fond-natsionalnogo-blagosostoyaniya-rossii/ (дата обращения: 08.05.2021).

22. Цена нефти марки Urals: 2000-2021 // Мировые финансы [Электронный ресурс]. - Режим доступа: http://global-finances. ru/tsena-nefti-marki-urals-po-godam/ (дата обращения: 08.05.2021).

23. Объем и структура государственного долга субъектов Российской Федерации и долга муниципальных образований // Министерство финансов Российской Федерации [Электронный ресурс]. - Режим доступа: https://minfin.gov.ru/ru/perfomance/ public_debt/subdbt/ (дата обращения: 08.05.2021).

24. Данные об исполнении местных бюджетов в Российской Федерации на 01.01.2021// Министерство финансов Российской Федерации [Электронный ресурс]. - Режим доступа: https://minfin.gov.ru/common/upload/library/2021/02/main/ Dannye_ob_ispolnenii_mestnykh_budzhetov_RF_-_01.01.2021.pdf (дата обращения: 08.05.2021).

\section{References}

1. Arlanova O. I., Zotikov N. Z., L'vova M. V. Local budgets: problems of formation, The Eurasian Scientific Journal, 2019, vol. 11, no. 5. Available at: https://esj.today/PDF/15ECVN519.pdf (accessed 08.05.2021). (In Russian).

2. Baronetskaya N. E. Assessment of local budget deficiency management and municipal debt, World Economy: Security Problems, 2020, no. 4, pp. 21-27. (In Russian).

3. Belostotskii A. A. The practice of executing consolidated budgets and reducing the level of public debt of the constituent entities of the Russian Federation, Actual Problems of the Development of Economic Entities, Territories and Systems of Regional and Municipal Government: Proceedings of the XV International Scientific and Practical Conference, Kursk, May 24-25, 2020, Kursk, Southwest State University, 2020, pp. 51-54. (In Russian).

4. Bzhikhatlov S. Kh., Nagaev A. A. Features of public debt management, Aktual'nye voprosy ekonomicheskikh nauk, 2016, no. 502 , pp. 11-16. (In Russian).

5. Dzhindzholiya A. O. Development of methods and instruments of management of the public (municipal) debt, Bulletin of Science and Education, 2019, no. 9-1 (63), pp. 54-58. (In Russian).

6. Zotikov N. Z., L vova M. V., Arlanova O. I. Features and problems of the formation of budgets of the constituent entities of the Russian Federation, Innovative Development of Economy, 2019, no. 2 (50), pp. 205-218. (In Russian).

7. Zotikov N. Z., L'vova M. V., Arlanova O. I. Features of formation of the federal budget revenues, The Eurasian Scientific Journal, 2019, vol. 11, no. 1. Available at: https://esj.today/PDF/12ECVN119.pdf (accessed 08.05.2021). (In Russian).

8. Roshchin N. S. Features of the organization of state and municipal borrowings in foreign countries, Biznes-obrazovanie v ekonomike znanii, 2020, no. 2 (16), pp. 76-82. (In Russian).

9. Mokhnatkina L. B. State and municipal debt: textbook, Orenburg, OSU, 2013, 180 p. (In Russian).

10. Tkachenko R. V. Budgetary regulation in the context of preventing the consequences of the spread of a new coronavirus infection in the Russian Federation, Lex Russica, 2021, no. 2 (171), pp. 64-79. (In Russian). https://doi.org/10.17803/17295920.2021.171.2.064-079

11. Norkin A. V., Smirnova I. A., Korobova V. F. The state borrowings of the Russian Federation in the context of the new concept of "debt sustainability" of the region, Vestnik Altaiskoi akademii ekonomiki i prava, 2019, no. 7-2, pp. 61-67. (In Russian). https://doi.org/10.17513/vaael.651

12. Russia's GDP by year: 1991-2020, Global Finances. Available at: http://global-finances.ru/vvp-rossii-po-godam/ (accessed 08.05.2021).

13. Reports on the implementation of the consolidated budget of the Russian Federation and state extra-budgetary funds for 2010-2018, Ministry of Finance of the Russian Federation. Available at: https://minfin.gov.ru/ru/statistics/conbud/ (accessed 08.05.2021). (In Russian).

14. Execution of the federal budget and budgets of the budget system of the Russian Federation for 2019, Moscow, Ministry of Finance of the Russian Federation, 2020. Available at: https://minfin.gov.ru/common/upload/library/2020/09/main/Ispolnenie_federalnogo_budzheta_2019_god.pdf (accessed 08.05.2021). (In Russian).

15. Execution of the federal budget and budgets of the budget system of the Russian Federation for 2020 (preliminary results), Moscow, Ministry of Finance of the Russian Federation, 2021. Available at: https://minfin.gov.ru/common/upload/library/2021/03/ main/Ispolnenie_2020_god.pdf (accessed 08.05.2021). (In Russian). 
16. Internal State Debt of Russia: 1993-2021, Global Finances. Available at: http://global-finances.ru/vnutrenniy-dolg-rossii/ (accessed 08.05.2021). (In Russian).

17. The US national debt in 2021 exceeded $\$ 28$ trillion, Global Finances. Available at: http:/global-finances.ru/gosdolg-ssha/ (accessed 08.05.2021). (In Russian).

18. US GDP by year: 1980-2021, Global Finances. Available at: http://global-finances.ru/vvp-ssha-po-godam/ (accessed 08.05.2021). (In Russian).

19. Russia's External Debt: 1994-2021, Global Finances. Available at: http://global-finances.ru/vneshniy-dolg-rossii/ (accessed 08.05.2021). (In Russian).

20. Gold and foreign exchange reserves of Russia: 1994-2021, Global Finances. Available at: http://global-finances.ru/zolotovalyutnyie-rezervyi-rossii/ (accessed 08.05.2021). (In Russian).

21. National Welfare Fund of Russia: 2008-2021, Global Finances. Available at: http://global-finances.ru/fond-natsionalnogo-blagosostoyaniya-rossii/ (accessed 08.05.2021). (In Russian).

22. Urals oil price: 2000-2021, Global Finances. Available at: http://global-finances.ru/tsena-nefti-marki-urals-po-godam/ (accessed 08.05.2021). (In Russian).

23. The volume and structure of the state debt of the subjects of the Russian Federation and the debt of municipalities, Ministry of Finance of the Russian Federation. Available at: https://minfin.gov.ru/ru/perfomance/public_debt/subdbt/ (accessed 08.05.2021). (In Russian).

24. Data on the execution of local budgets in the Russian Federation as of January 1, 2021, Ministry of Finance of the Russian Federation. Available at: https://minfin.gov.ru/common/upload/library/2021/02/main/Dannye_ob_ispolnenii_mestnykh_budzhetov_RF_-_01.01.2021.pdf (accessed 08.05.2021). (In Russian). 